Varia

\title{
The European concept of regulated markets and its significance for the Romanian incrimination norm of market abuse - A Case Comment, ECJ Case C-248/11, Nilaş and others -
}

\author{
Doris Alina Şerban ${ }^{1}$
}

The judgment under review here is relevant from two perspectives. Firstly, it constitutes a first for Romanian criminal law, since it is the first to provide a direct example on how Romanian criminal law intersects EU law. Secondly, at the European level, its relevance stems from the fact that the judgment is the first to bring forward for discussion the meaning of a European key definition for capital markets, namely the "regulated market". Before analysing the interpretative solution given by the ECJ, the author examines the admissibility of the reference in terms of its utility and object: the application or the interpretation of EU law. As regards the judgment's utility for the national proceedings, the author argues that the interpretation of the European concept of a "regulated market" could function strictly as a guide for the Romanian court. In relation to its object, the author shows that the problem referred by the national court was indeed one of interpretation and not one of direct EU law application. In terms of merit, the author considers that the interpretative solution given by the ECJ is not at all surprising, since it was the only rational solution: a market that has not been authorized by the competent national authority and does not meet the requirements outlined by Title III of MiFID cannot be considered a "regulated market".

\section{Introduction}

The European Court of Justice's (ECJ) judgment, which shall be commented upon herein, does not distinguish itself by virtue of the exceptional difficulty of the legal problems that it solves ${ }^{2}$ but rather by virtue of the adjacent problems that it raises.

At the same time, the judgment represents a first for Romanian law. Its singularity stems both from the context in which the problem of interpretation was raised ${ }^{3}$ (during a criminal trial) and from the particular effects that the decision produces

\footnotetext{
${ }^{1}$ Doris-Alina Şerban, Ph. D. student at Babeş-Bolyai University, Romania.

${ }^{2}$ Confirming the simplicity of the legal matter, the ECJ deemed it appropriate that the issue be resolved within the procedure stipulated under Art. 20 of the ECJ Statute by a panel of five judges, without a submission from the Advocate-General.
} 
due to this context. At a European level, the ECJ judgment is the first to bring forward the meaning of a European key definition for the capital market on the table for discussion, namely the "regulated market".

All these characteristics make the decision susceptible to comments.

The first issue discussed here is the admissibility of the reference for a preliminary ruling both in terms of its usefulness regarding the national dispute and in terms of its object, the interpretation or application of European law. Since the focus of this study is the ECJ judgment itself, we cannot conclude this paper without analyzing the interpretative solution offered by the ECJ to the questions of the referring court.

\section{The dispute in the main proceedings and the questions referred}

Through a decision taken on 13 May 2011, the Cluj Court of Appeal made a reference for a preliminary ruling under 267 TFEU. The reference was made during the criminal proceedings against some Romanian citizens charged with market manipulation on the so-called RASDAQ financial market. The problem that generated the need to make such a reference was that regarding the legal status of the market.

The determination of this status was considered to be essential for the existence/ non-existence of the crime, given the fact that in Romanian law (Law No 297/ $2004^{4}$ that transposes Directive 2003/6/EC and Directive 2004/39/EC) market abuse is only incriminating when committed in relation to financial instruments admitted to trading on a regulated market or for which a request for admission to trading on such a market has been made. If this market was to be considered regulated (the prosecution's point of view) then the actus reus could have existed. On the other hand, if the so-called RASDAQ market was to be qualified as nonregulated, then the defendants' acquittal would have been mandatory, given the fact that the national incrimination norm does not apply to such markets.

Consequently, the defendants' representatives in the main proceedings contested the view of the prosecution regarding the status of RASDAQ and, therefore, asked the referring court to determine, as a preliminary issue, whether the RASDAQ market is a "regulated market" within the meaning of Law No 297/2004.

\footnotetext{
${ }^{3}$ An ad hoc statistical study reveals that from Romania's EU accession (2007) until now (15 June 2012), Romanian courts have made forty-one references for a preliminary ruling. What gave the Romanian courts momentum was the entry into force of a so-called pollution tax levied on motor vehicles on their first registration in Romania. This tax created discrimination between the second-hand vehicles purchased in other EU Member States and those purchased on the domestic market. In this context, the Romanian courts have asked the ECJ to rule on the compatibility of such legislation with European law (primary and secondary). In criminal law, in addition to the reference for a preliminary ruling mentioned herein, one other single reference has been made (case C-396/11), concerning the interpretation of Council Framework Decision 2002/584/JHA of 13 June 2002 on the European arrest warrant and the surrender procedures between Member States. For details on the content of the questions and the national proceedings in which they appeared, see the case information accessible at www.curia.europa.eu

${ }^{4}$ M. Of. No 571, 29. 06. 2004, Part I.
} 
Considering these circumstances, the referring court decided to stay the proceedings and refer the following questions to the ECJ for a preliminary ruling:

(1) Can Article 4[1](14) and Articles 9 to 14 of [Directive 2004/39] (...) be interpreted as applying both to the main trading market authorized by the competent national authority [CNVM] and to the secondary trading market, which has been incorporated into the former since 2005 (...) but has continued to be regarded as separate from the regulated market, even though its legal status has not been clarified by way of legislation?

(2) Must the provisions of Article 4[1](14) of [Directive 2004/39] be interpreted as meaning that the concept of a regulated market does not encompass those trading systems which do not comply with the provisions of Title III of [Directive 2004/ 39]?

(3) Must the provisions of Article 47 of [Directive 2004/39] be interpreted as meaning that a market which has not been notified by a competent national authority and is not included in the list of regulated markets is not subject to the legal rules applicable to the regulated markets, in particular as regards the rules designed to prevent market abuse under Directive 2003/6/EC?

\section{The capital market - object of regulation in European and Roma- nian law}

Before directly addressing the topics of concern of the present study, we consider that a brief overview of the European and Romanian regulatory framework of the capital market is necessary.

\section{Capital markets and market abuse in EU Law}

Currently ${ }^{5}$, the core of the European regulatory system of financial markets is Directive No EC/2004/39 ${ }^{6}$ on markets in financial instruments (MiFiD). ${ }^{7}$ This directive defines the essential structures of the capital market: the regulated market (Art. 4[1] (14) and Title III), the multilateral trading facility, the financial instruments, etc. It also lays down the minimum requirements and procedures for the authorization and operation of investment companies, the regulations for the appointment of competent national authorities, the extent of their powers or the

\footnotetext{
${ }^{5}$ The dynamics that characterize this field are also translated into a continuous need to adapt the European regulatory framework. Precisely because of this, various amendment proposals are currently under discussion in the European Union: (i) a proposal for a directive on markets in financial instruments repealing Directive 2004/39/EC of the European Parliament and of the Council, COM (2011) 656 final; (ii) a proposal for a regulation on markets in financial instruments and amending Regulation (EMIR) on OTC derivatives, central counterparties and trade repositories, COM (2011) 652 final; (iii) a proposal for a directive on criminal sanctions for insider dealing and market manipulation, COM (2011) 651 final; and (iv) a proposal for a regulation on insider dealing and market manipulation (market abuse), COM (2011) 654 final.

${ }^{6}$ OJ 2004 L 145/I.

${ }^{7}$ In addition to this Directive, a series of other European legal acts regulate specific aspects of the capital market. See http://eurlex.europa.eu.
} 
principles that should govern the mutual cooperation between the competent authorities of EU Member States.

As regards market abuse, Directive No EC/2003/6 $6^{8}$ (MAD) is the European legal instrument ${ }^{9}$ that requires EU Member States to sanction the whole range of behaviors encompassed in the concept of "market abuse"10. According to the provisions $^{11}$ of the directive, this obligation applies only in the case of abusive actions committed in relation to financial instruments admitted to trading on a regulated market or for which a request for admission to trading on such a market has been made.

MAD requires a minimum standard of harmonization, so that the minimum obligation of EU Member States is to apply effective, proportionate and dissuasive sanctions. This minimum obligation does not interfere with their right to incriminate such acts.

\section{The capital market and market abuse in Romanian law}

In Romanian law, Law No 297/2004 is the one which transposes the European regulatory framework. Essentially, the law literally copies the fundamental provisions of the corresponding European regulations. As a result, MiFiD's definition of the regulated market is undeviatingly adopted in the national law.

With regard to market abuse, the national legislature proceeds in an identical manner: the European descriptive norms on market abuse are copied word-forword in the disposition of the national incrimination norm. ${ }^{12}$ As far as the sphere of applicability is concerned, Art. 253 of the national law reiterates the corresponding provisions contained in Art. 9 of MAD. Therefore, the incrimination norm is only applied to abusive market actions committed in relation to financial instruments admitted to trading on a regulated market or for which a request for admission to trading on such a market has been made.

\footnotetext{
${ }^{8}$ OJ 2003 L 96/I.

${ }^{9}$ The European market abuse regulatory framework is structured on three levels (Lamfalussy structure): Directive No EC/6/2003- level I; Directive No EC/124/2003, Directive No EC/125/2003, Directive No EC/72/2004 and Regulation (EC) No 2273/2003- level II; three guidelines issued by European Securities and Market Regulators (ESMA) on the interpretation and implementation of the MAD- level III.

${ }^{10}$ Insider dealing stricto sensu with its adjacent actions (disclosing inside information - "tipping" and recommending or determining another person to acquire or dispose of financial instruments on the basis of inside information "tuyautage") and market manipulation.

${ }^{11}$ Pursuant to Art. 9 from MAD, the directive shall apply to any financial instrument admitted to trading on a regulated market in at least one Member State, or for which a request for admission to trading on such a market has been made, irrespective of whether or not the transaction itself actually takes place on that market.

12 The national legislature thus opted for an undifferentiated incrimination of market abuse, attracting all illegal conducts under the MAD into the criminal norm. At a European level however, it can be noticed that not all Member States have opted for such an undifferentiated incrimination. For a detailed presentation of the different policies in terms of market abuse incrimination, see Commission Staff Working Paper Assessment Impact accompanying Proposal for a regulation on insider dealing and market manipulation and the Proposal for a Directive of the European Parliament and of the Council on insider dealing and criminal Sanctions for market manipulation, SEC (2011) 1217 final, p 28.
} 


\section{Short presentation of the RASDAQ market}

The features of RASDAQ are essential in resolving the interpretative problem reported by the national court, since the Gordian knot of the national dispute was whether or not a market with the characteristics of RASDAQ may fall within the concept of a "regulated market". Consequently, a short presentation of RASDAQ prior to any analysis would seem to be appropriate:

- the RASDAQ market was founded in 1996, on the basis of Law No 52/ $1994 i^{13}$

- after Law No 297/2004 entered into force, the RASDAQ market has not been adapted to the new legal provisions and has continued to function outside the two possible legal shapes that a financial market can take (regulated market or multilateral trading facility). As such, the competent national authority has not issued any decision that authorizes RASDAQ to function as a regulated market or multilateral trading facility;

- the RASDAQ market has its own operating conditions, different from those established by Law No 297/2004 for the regulated markets; ${ }^{14}$

- on 1 December, 2005, Bursa Electronică Rasdaq S. A. ${ }^{15}$ merged with Bursa de Valori Bucureşti S. A., the former being incorporated into the latter. The legal person resulting from that merger was called Bursa de Valori Bucureşti S. A. and was required to manage two different markets: the regulated market Bursa de Valori București (B.V.B.) and the RASDAQ market. After this merger, the RASDAQ market continued to operate as an independent market in relation to the B. V.B. regulated market.

- As to the legal status of the RASDAQ market, we must mention that, following a request in this regard made by the referring court, the competent national authority expressed its point of view, showing that the RASDAQ market has never been authorized as a regulated market and, therefore, it was not included on the Regulated Markets List drawn up by the European Commission and published in the Official Journal of the European Union ${ }^{16}$.

\footnotetext{
${ }^{13}$ M. Of. No 210, 11. 08. 1994, Part I.

14 The operating conditions of RASDAQ are regulated by Regulation no. 2/2002 issued by the competent national authority. The differences between the operating conditions of RASDAQ and those of the regulated market are multiple: RASDAQ's requirements for admission to trading are essentially different from those existing on the regulated market; there is no requirement to report insider transactions, etc.

${ }^{15}$ S.C. Bursa de Valori Bucureşti was at that time the market operator for the regulated market B. V. B.

${ }^{16}$ Pursuant to Art. 47 of MiFiD each Member State shall draw up a list of the regulated markets for which it is the home Member State and shall forward that list to the other Member States and the Commission. A similar communication shall be effected in respect of each change to that list. The Commission shall publish a list of all regulated markets in the Official Journal of the European Union and update it at least once a year. The Commission shall also publish and update the list on its website each time the Member States communicate changes to their lists. The last such list was published in the Official Journal of the European Union on 15 June, 2011, and it's available at http://eur-lex.europa.eu/LexUriServ/LexUriServ.do?uri=OJ:C:2011:209:0021:0028:EN: PDF
} 


\section{Admissibility issues of the reference for a preliminary ruling}

\section{The usefulness of the interpretation of a European legal concept included in a Directive, for the interpretation of the corresponding national concept included in an incrimination norm}

Before considering the substantive issue raised by the national court, we will focus on the extent to which the answers of the ECJ to the questions referred could have had the ability to terminate the internal dispute regarding the national legal classification of RASDAQ. More specifically, the question that we will try to answer at this time is whether the reference for a preliminary ruling was admissible in terms of its relevance for the national proceedings.

As is already known, the usefulness of the answer given by the ECJ for the national proceedings is not only an opportunity criterion, but, more importantly, it represents an admissibility condition of the reference for a preliminary ruling. ${ }^{17}$

This condition of jurisdiction has never been interpreted by the ECJ in an extreme manner. Many times, the ECJ ruled in favor of the admissibility, even though the effective usefulness of the answer for the national dispute might have been considered controversial. ${ }^{18}$

The ECJ's eagerness to cooperate with the national courts becomes particularly noticeable in those situations in which the interpretative matter raised by the referring court involves the interpretation of a European concept included in a directive which, through its transposition in the national law, was integrated into a national incrimination norm.

Due to certain peculiarities of this paradigm (as presented infra), it will not be always possible for the national court to ad literram use the interpretation of the European concept given by the ECJ. Therefore, depending on the circumstances, the usefulness (and, therefore, relevance) of the reference for a preliminary ruling may sometimes be brought into question.

\section{a) Characteristics of the paradigm}

As a normative typology of secondary EU law, the essence of the directive is that its effectiveness is contingent on its implementation by EU Member States ${ }^{19}$. The mediated effectiveness rule is confirmed by a solid ECJ case-law that not only

\footnotetext{
${ }^{17}$ European Court of Justice (ECJ), 1. 10. 2009, case C-567/07, (Woningstichting Sint Servatius) [2009], ECR 9021, margins no 42 and 43: "In that regard, it should be recalled at the outset that although, in view of the division of responsibilities in the preliminary ruling procedure, the referring court alone can determine the subject-matter of the questions it proposes to refer to the Court, the Court has also stated that, in exceptional circumstances, it will examine the conditions in which the case was referred to it by the national court, in order to assess whether it has jurisdiction. That is the case in particular where the problem referred to the Court is purely hypothetical or where the interpretation of a Community rule which is sought by the national court has no relation to the actual facts of the main action or to its purpose $[\ldots] "$.

${ }^{18}$ As in the present case.

${ }^{19}$ Pursuant to Art. 288 TFEU, the directive shall be binding upon each Member State to which it is addressed with regard to the result to be achieved, but shall leave the choice of form and method to the discretion of the national authorities.
} 
reaffirms the distinctive and defining features of the directive in comparison to the regulation, but also outlines the strict conditions in which the non-transposed or incorrectly implemented directive can be directly applicable ${ }^{20}$ :

- the directive must produce effects in favor of the individual;

- the provisions of the directive must be sufficiently precise and formulated in an unconditional manner, so as to enable their direct application.

Since criminal liability produces effects against the individual, the first condition for direct effectiveness excludes ab initio any direct effect of the directive, when invoked as the singular or complementary basis for criminal liability. Therefore, a hypothetical direct effect of the directive as the basis of criminal liability cannot be invoked in order to compensate the EU Member State's failure to fully comply with the obligation imposed by the directive to sanction (criminally or not) the illegal conduct contained in it. ${ }^{21}$ The only solution in such cases is the legislature's intervention, voluntarily or forced, by an infringement procedure triggered against the State that failed to implement or to correctly transpose the directive. ${ }^{22}$

And yet, when the national judge finds himself in the presence of such a paradigm, he cannot entirely ignore the wording of the directive. The reason is simple: on account of the European principle of sincere cooperation ${ }^{23}$ there is the absolute presumption that the national law implementing the Directive embodies the legislature's will to implement the directive in a correct and complete manner. ${ }^{24}$ Therefore, the national judge must interpret the national norm using the European provisions as a landmark. This is usually the reasoning behind the decision of the national judge to make a reference for a preliminary ruling when confronted with such a paradigm ${ }^{25}$.

Precisely because of such features, the influence of European law on national criminal law can only be limited, in such a situation. Therefore, in the present case, as we will further demonstrate, an interpretative solution from the ECJ with regard

\footnotetext{
${ }^{20}$ For further reading, see Damien Chalmers, Gareth Davies şi Giorgio Monti, European Law: Cases and materials, ed. 2, Cambridge University Press, Cambridge, 2010, p 286 et. seq.

21 The same conclusion has been reached in the core case-law of the ECJ: "Nevertheless, the obligation of the national court to refer to the content of the directive when interpreting the relevant rules of its national law is limited by the general principles of law that are part of Community law and in particular by the principles of legal certainty and non-retroactivity. Thus, in its judgment of 11 June 1987 in Case 14/86 Pretore di Salò v X [1987] ECR 2545, the Court ruled that a directive cannot, in itself and independent of a national law adopted by a Member State for implementation, have the effect of determining or aggravating the criminal liability of persons who act in contravention of the provisions of that directive"- ECJ, 8. 10. 1987, case C-80/86, (Kolpinghuis Nijmegen), [1987] ECR 3969 , margin no 13

${ }^{22}$ In relation to the transposition of MAD, the European Commission triggered an infringement procedure against Luxemburg (case C-236/06) for its failure to adopt, within the prescribed period, the provisions necessary to comply with MAD. The Commission has subsequently withdrawn this action.

${ }^{23}$ According to art. 4 (3) TEU: "The Member States shall take any general or special measure necessary to ensure fulfillment of the obligations arising out of the Treaties or resulting from the acts of the institutions of the Union". The obligation to refer to European law will be much more explicit when the Directive will require Member States to incriminate certain behaviors (as it may happen post - Lisbon). For a detailed overview of the changes brought by the Lisbon Treaty in the criminal field see Kai Ambos, Europäisches Strafrecht post-Lisbon, Gottingen, 2011.

${ }^{24}$ In this respect, see Helmut Satzger, Internationales und Europäisches Strafrecht, Baden-Baden, 2005, p. 119.

${ }^{25}$ As in the present case, in which the national judge considered that he could not solve the preliminary issue without determining whether Art. 4 (14) of MiFID is to be interpreted as including a market with the characteristics of RASDAQ and, as a consequence, if such a market is subject to the European provisions regarding market abuse.
} 
to the European concept of "regulated market" could not have had the lasting effect of permanently shaping the national incrimination norm.

\section{b) The effects of the European concept's interpretation on the homon- ymous national concept and the national incrimination norm}

The limited effects and therefore the limited usefulness of the EU law interpretation on the national norm that incriminates market abuse are best revealed by discussing the two alternatives at the disposal of the ECJ in the present case:

a) In the event that, through the interpretation of EU law, the ECJ would have concluded that the European notion of "regulated market" also includes a market with the features of RASDAQ, the solution would have contradicted RASDAQ's national non-regulated market status, as confirmed by the competent national authority $^{26}$.

In this case, the divergence between the two concepts could not have been remedied by the national judge by aligning the national concept with the European one, due to the directive's mediate effectiveness and the criminal context in which the interpretative problem was raised.

As to the criminal context, it is known that unlike other legal matters that enjoy some flexibility, including with regard to the interpretation of the norm, under criminal law the interpretation may only be strict - lex stricta ${ }^{27}$.

Therefore, in criminal law, the interpretation of the national concept by employing the European point of reference can only be achieved if the incrimination norm allows for certain discretion ${ }^{28}$, in order for the extensive interpretation to be compatible with the abovementioned principle.

In the case at hand, no such discretion existed. The exact definition of the regulated market, deriving from a series of national provisions governing all its aspects (authorization, operating conditions and extinction ${ }^{29}$ ), completely reduced that leeway in the interpretation of the national norm, which would have made an interpretation using the European law as an essential landmark possible ${ }^{30}$.

\footnotetext{
${ }^{26}$ Even the national court admitted in its application that the RASDAQ market has not been qualified as a regulated market at national level.

${ }^{27}$ Fundamental principle in all EU Member States, stipulated in Art. 49 of the EU Charter of Fundamental Rights and in Art. 7 of the European Convention of Human Rights.

28 "It is for the national court to interpret and apply the legislation adopted for the implementation of the directive in conformity with the requirements of Community law, in so far as it is given discretion to do so under the national law" - ECJ, 10. 04. 1984, case C-14/83, (Sabine von Colson and Elisabeth Kamann), [1984] ECR 1891, margin no 28.

${ }^{29}$ Title IV of Law no. 297/2004 and Title II of Regulation no. 2/2006, issued by the competent national authority.

${ }^{30}$ Precisely the rigorous definition of the regulated market distinguishes the present situation from all other references for a preliminary ruling that led to the interpretation of certain terms of the MAD Directive: case C-19/ 11, Case C-445/09, Case C-45 / 08 Case C-391/04, C-384/02. All these cases attempted to interpret terms (words or phrases) which lacked explanations (technical or otherwise) with regard to their normative significance. The lack of any further explanation increased their elasticity and therefore the possibility to interpret them in accordance with the interpretation of EU law. For example, in Case C-445/09, the national court asked the ECJ to determine whether Art. 1 (2) of the MAD must be interpreted as requiring, in order for the price of one or more financial instruments to be considered to have been fixed at an abnormal or artificial level year, that that price must maintain an abnormal or artificial level for more than a certain duration. It is clear that in this case, it would have been easier
} 
If the national judge, by ignoring all these arguments, would have tried to create compatibility between EU and national law, the criminal liability of the defendants would not have been based solely on the national incrimination norm, but on a lex tertia, a mixture of national and EU law, incompatible with the principle of legality ${ }^{31}$.

Consequently, in this first case, the only way to adapt the national criminal law to European law was through the intervention of the legislature, either voluntary or forced by an infringement procedure.

b) The limited effects of the EU law interpretation on the interpretation of the national incrimination norm are also proven by the reverse hypothesis, which coincides with the solution given by the ECJ in the present case.

Even if the ECJ had established that an abstract market identical to RASDAQ cannot qualify as a regulated market, the national dispute regarding the interpretation of the national concept would not have been (or rather is not, since this is the solution preferred by the ECJ) conclusively settled.

MAD requires a minimum standard of harmonization, which means that the legislature could have chosen to apply the incrimination norm, as well as for transactions on non-regulated markets in terms of MiFID and MAD ${ }^{32}$. As such, it may have been theoretically possible for the national legislature to choose to extend the applicability of market abuse on markets that do not meet EU regulated market requirements ${ }^{33}$. As a result, in this case as well, the national norm would have remained the reference point for criminal liability and the interpretation of European law could have represented a simple foothold in the interpretation process.

Therefore, as shown supra, the ECJ solution could not have determined the exact sphere of criminal liability for market abuse in Romanian criminal law. It could function solely as a guide for the interpretation of the national incrimination norm.

\section{Was the issue raised by the national judge a question of interpretation or a question of application of European law?}

The admissibility of the reference also depends on the answer to this question, since, pursuant to Art. 267 TFEU, the object of such a reference cannot be the application of European law but only its interpretation. Several defendants in the national criminal proceedings claimed inadmissibility precisely on these grounds.

\footnotetext{
for the national court to use the ECJ answer directly, since there weren't any national regulations that detailed its meaning.

${ }^{31}$ As far as the importance of this principle at the EU level is concerned, we refer to the Court's considerations: "This principle implies that legislation must clearly define offences and the penalties which they attract. This condition is met when the concerned individual is in a position, on the basis of the wording of the relevant provision and with the help of the interpretative assistance given by the courts, to know which acts or omissions will make him criminally liable"- ECJ, 3. 05. 2007, case C-303/05, (Advocaten voor de Wereld VZW v Leden van de Ministerraad), [2007] ECR 3633, margin no 3

${ }^{32}$ Criminal policy encountered in EU Member States such as the United Kingdom or Germany.

${ }^{33}$ Here, this is not the case. The argument was invoked mostly to emphasize the relevance of the national norm and the status of a simple recommendation that the interpretation of the European Law may have.
} 
The defendants considered that the first question was a question of fact since, in order to determine whether the RASDAQ market is a "regulated market", it is sufficient to ascertain whether it was authorized by the CNVM to operate as such.

As far as we are concerned, the reference for a preliminary ruling was admissible in this regard. In their substance, the questions raised by the national judge did not concern a question of fact but looked for an interpretation of EU law.

The arguments presented by the parties can only be considered accurate if we adopt a hyper formal approach to the notion of interpretation.

At first glance, the purpose of the first question was the application of EU law. Even its wording partially indicated such a conclusion, since the national judge asked the ECJ to determine whether Article 4, paragraphs 14 and Art. 9-14 of Directive 2004/39/EC can be interpreted as applying to such secondary markets as well. This content created the impression that the referenced question was beyond the competence set by Art. 267 TFEU, as developed in the ECJ case law $^{34}$.

This confusion between application and interpretation is certainly the result of the very subtle boundary that exists between the application and the interpretation of EU law, a subtle boundary that can also be identified in the present case ${ }^{35}$. Had the question remained in the form proposed by the national judge, it would have rightly raised the suspicion of claiming a direct application of EU law. However, if the question had been reformulated, asking the ECJ to decide whether an abstract market with the same features as RASDAQ falls within the European definition of a regulated market (without making any specific reference to the RASDAQ market itself) the problem would have become one of interpretation. Without any doubt, it would be illogical if such differences in form could determine the admissibility or inadmissibility of the preliminary reference.

The ECJ approached this matter in the same manner. It showed that from the content of the application it can be inferred that the national court wishes to know the manner in which the European concept of "regulated market" should be interpreted and, therefore, reformulated the questions addressed by the national court. $^{36}$

\footnotetext{
34 "On the other hand, the Court has no jurisdiction to give a ruling on the facts in an individual case or to apply the rules of Community law which it has interpreted to national measures or situations, since those questions fall within the exclusive jurisdiction of the national court" - ECJ, 1. 06. 2007, case C-295/05, (Omni Metal Service), [2007] ECR 2999, margin no. 17. The situation in this case was similar to the judgment herein commented upon. By drawing a parallel between these two cases, we can note that the ECJ considered that it is not competent to give a direct qualification of an objective element of national dispute (in the case cited it refused to directly apply EU provisions in order to give an explicit qualification for a wire cable, affirming that such qualification is beyond its jurisdiction to interpret European law). However, the Court reformulated the questions, establishing that accordingly, the question must be understood as asking whether heading GC 020 of the green list of wastes must be interpreted as covering electrical wire and, if so, under what conditions.

${ }^{35}$ In this respect see also, Morten Broberg, Niels Fenger, Preliminary References to the European Court of Justice, Oxford, 2010, p. 136 et. seq.

${ }^{36}$ In this case, we can also identify the indisputable tendency of the ECJ to encourage and help national courts as much as possible to solve cases in which points of intersection with EU law arise, even when the activation of these cooperation mechanisms requires a prior reformulation of the questions referred by the national courts.
} 


\section{The ECJ Judgment}

Through a synthetic approach, the ECJ established that the interpretative problem boils down to whether the European concept of a regulated market (as defined in MiFID) includes a market that has the same characteristics as RASDAQ and therefore deemed it appropriate to unify the first two questions referred by the national court.

In terms of merit, the Court found that the legal issue raised is not at all difficult, since the "regulated market" concept is rigorously defined by the European legislation. In order for a market to be qualified as regulated, three conditions need to be fulfilled, as outlined in Art. 4 [1] (14) of MiFID:

- the market must be managed by a market operator;

- the market must be authorized by the competent national authority;

- the market must operate at all times in accordance with the requirements set out in Title III of said directive.

Rightly, the ECJ held that the existence of any other circumstances such as the merger between two distinct market operators or the fact that the market uses the same trading platform as a regulated market, are neutral circumstances (since these circumstances are not encompassed in its definition) that cannot have any impact on its qualification.

The Court also overturned the argument invoked by the national court which stated that if abusive conducts on the RASDAQ market are removed from the sphere of market abuse, this could damage market integrity and investor confidence. In this respect, the ECJ showed that investor confidence must be primarily protected through a clear legal framework: "it is clear in particular from recitals 2, 5 and 44 in the preamble to Directive 2004/39, that its objectives consist, inter alia, in protecting investors, preserving the efficient and orderly functioning of financial markets and the transparency of transactions. To permit a market which does not satisfy the conditions set out in paragraph 43 of the present judgment to be classified as a regulated market solely because it is operated by the operator of another market authorized as a regulated market risks undermining those objectives"- ECJ, 21. 03. 2012, case C-248/11, (Nilaş and others), margin no 48.

Based on this brief but accurate argumentation, the ECJ gave a clear answer to the first two questions referred by the national court, ruling that Article 4(1)(14) of Directive 2004/39 must be interpreted as meaning that a market in financial instruments which does not satisfy the requirements in Title III of that directive does not fall within the concept of a "regulated market", as defined in that provision, notwithstanding the fact that its operator merged with the operator of such a regulated market.

Once this problem was solved, the Court proceeded to determine whether Article 47 of MiFID must be interpreted as meaning that the inclusion of the market on the list of regulated markets mentioned therein is a prerequisite for the classification of that market as regulated. 
By using a series of arguments drawn from the European definition of the regulated market, the Court concluded that its inclusion in the list published in the EU Official Journal cannot be qualified as a prerequisite for the existence of a regulated market.

First, the Court held that the legal prerequisites of the market's existence do not include its publication in the EU Official Journal list. Even if Art. 47 is included in Title III of MiFiD and one of the conditions for the existence of the regulated market is to be in accordance with the provisions of Title III, the Court rejected the idea that its inclusion in the aforementioned list can be considered a condition for its existence: "as set out in paragraph 42 of the present judgment, authorization as a regulated market must, pursuant to the first subparagraph of Article 36(1) of Directive 2004/39, be reserved to trading systems which comply with the provisions of Title III of that directive. Since the inclusion on the list referred to in Article 47 of that directive must be subsequent to the authorization, it cannot logically constitute a condition of authorization", ECJ, 21. 03. 2012, case C-248/11, (Nilaş and others), margin no 53.

In order to consolidate its argumentation, the Court made a comparison with the old European legislation ${ }^{37}$, where the inclusion of the market in the relevant list was an explicit condition of existence for the regulated market. In the view of the Court, the express abrogation of this condition in the new definition indicates that the non-inclusion of the market in such list cannot preclude the qualification of the market as regulated.

On the basis of these arguments, the Court concluded that the answer to the third question is that Article 47 of Directive 2004/39 must be interpreted as meaning that the inclusion of a market on the list of regulated markets referred to in that article is not a precondition for the classification of that market as a regulated market within the meaning of that directive.

\section{Conclusive remarks}

The judgment under review here represents a first for Romanian criminal law, since it's the first decision that provides a direct example of how Romanian criminal law intersects EU law and how such intersections must be addressed. At the same time, at EU level, this is the first judgment that discusses the European definition of the "regulated market".

First, we have shown that the interpretation of the European concept of a regulated market could have functioned strictly as a guide for the national court. Given the characteristics of the relevant European regulations and the national context in which the interpretative matter occurred, the solution offered by the

\footnotetext{
${ }^{37}$ Previously, the regulated market was defined by Art. [1] (13) from Directive 93/22/EC
} 
ECJ could not have had the ability to modify, one way or another, the Romanian incrimination norm and criminal liability.

In terms of merit, the Court offered the only rational solution. It ruled that under EU law, a market that has not been authorized by the competent national authority and that does not meet the requirements outlined by Title III of MiFID cannot be considered a "regulated market". With regard to the third question, the Court held that the publication of a market on the list compiled by the European Commission pursuant to Art. 47 of MiFID cannot be considered a prerequisite for the existence of such a market. 
https://doi.org/10.5235/219174413808445892

Generiert durch IP '172.22.53.54', am 26.04.2023, 11:59:16. 